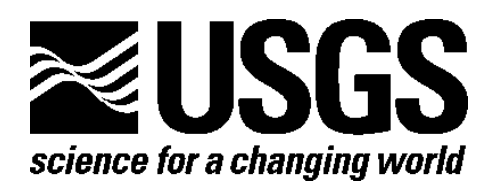

\title{
Emergency Assessment of Post-Fire Debris-Flow Hazards for the 2013 Springs Fire, Ventura County, California
}

By Dennis M. Staley

Open-File Report 2014-1001 


\section{U.S. Department of the Interior \\ SALLY JEWELL, Secretary}

\section{U.S. Geological Survey \\ Suzette M. Kimball, Acting Director}

U.S. Geological Survey, Reston, Virginia: 2014

For more information on the USGS-the Federal source for science about the Earth,

its natural and living resources, natural hazards, and the environment-visit

http://www.usgs.gov or call 1-888-ASK-USGS

For an overview of USGS information products, including maps, imagery, and publications, visit $h$ ttp://www.usgs.gov/pubprod

To order this and other USGS information products, visit http://store.usgs.gov

Suggested citation:

Staley, D.M., 2014, Emergency assessment of post-fire debris-flow hazards for the 2013 Springs Fire, Ventura County, California: U.S. Geological Survey Open-File Report 2014-1001, 10 p., 3 plates, http://dx.doi.org/10.3133/ofr20141001.

ISSN 2331-1258 (online)

Any use of trade, firm, or product names is for descriptive purposes only and does not imply endorsement by the U.S. Government.

Although this information product, for the most part, is in the public domain, it also may contain copyrighted materials as noted in the text. Permission to reproduce copyrighted items must be secured from the copyright owner. 


\section{Contents}

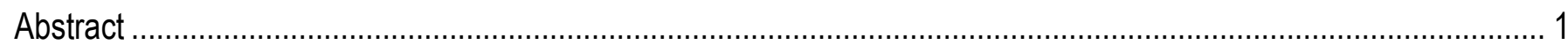

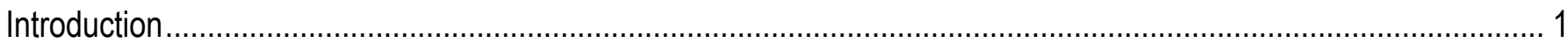

Physical Setting of the Springs Fire Burn Area

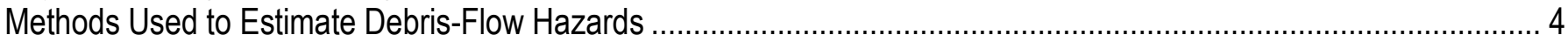

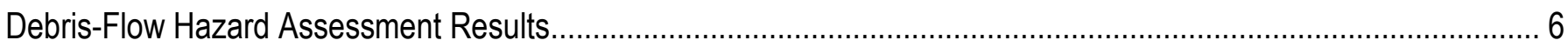

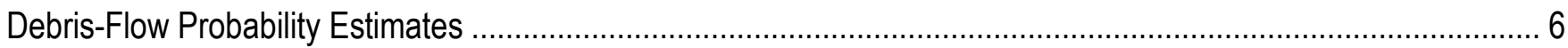

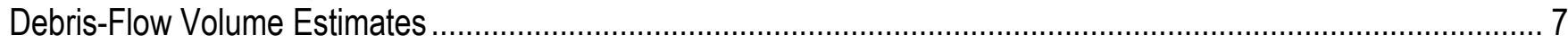

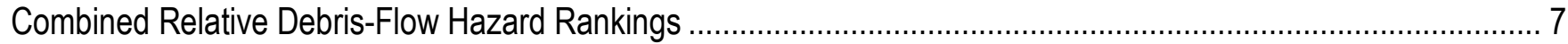

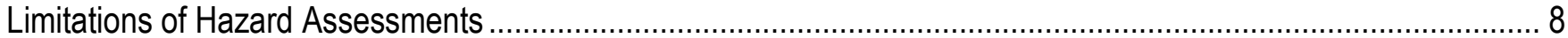

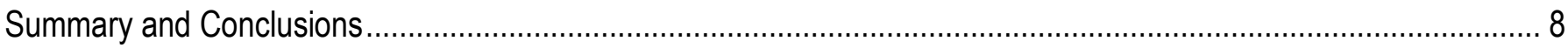

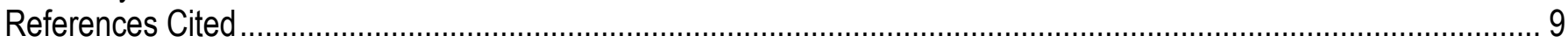

\section{Figures}

Figure 1. Overview map of the Springs fire burn area................................................................................ 3

Figure 2. Burned severity map of the Springs fire burn area....................................................................... 4

\section{Table}

Table 1. Summary of the total percentage of stream length within each probability, volume, and combined hazard ranking for the Springs fire burn area

\section{Plates}

Plate 1. Estimated probability of post-fire debris flows in the area burned by the 2013 Springs fire, Ventura County, California link

Plate 2. Estimated volume of post-fire debris flows in the area burned by the 2013 Springs fire, Ventura County, California link Plate 3. Combined relative debris-flow hazard in the area burned by the 2013 Springs fire, Ventura County, California. link 


\section{Conversion Factors and Datums}

\begin{tabular}{lcl}
\hline \multicolumn{1}{c}{ Multiply } & By & \multicolumn{1}{c}{ To obtain } \\
\hline millimeter $(\mathrm{mm})$ & 0.03937 & inch (in.) \\
meter $(\mathrm{m})$ & 3.281 & foot $(\mathrm{ft})$ \\
kilometer $(\mathrm{km})$ & 0.6214 & mile $(\mathrm{mi})$ \\
\hline & Area & \\
\hline hectare $(\mathrm{ha})$ & 2.471 & acre \\
square kilometer $\left(\mathrm{km}^{2}\right)$ & 247.1 & acre \\
square kilometer $\left(\mathrm{km}^{2}\right)$ & 0.3861 & square mile $\left(\mathrm{mi}^{2}\right)$ \\
square meter $\left(\mathrm{m}^{2}\right)$ & 10.76 & square foot $\left(\mathrm{ft}^{2}\right)$ \\
\hline & Volume & \\
\hline cubic meter $\left(\mathrm{m}^{3}\right)$ & 35.31 & cubic foot $\left(\mathrm{ft}^{3}\right)$ \\
\hline & Flow rate & \\
\hline millimeter per hour $(\mathrm{mm} / \mathrm{h})$ & 0.03937 & inch per hour $(\mathrm{in} / \mathrm{h})$ \\
\hline
\end{tabular}

Vertical coordinate information is referenced to the North American Vertical Datum of 1988 (NAVD 88). Horizontal coordinate information is referenced to the North American Datum of 1983 (NAD 83). 


\title{
Emergency Assessment of Post-Fire Debris-Flow Hazards for the 2013 Springs Fire, Ventura County, California
}

\author{
By Dennis M. Staley
}

\begin{abstract}
Wildfire can significantly alter the hydrologic response of a watershed to the extent that even modest rainstorms can produce dangerous flash floods and debris flows. In this report, empirical models are used to predict the probability and magnitude of debris-flow occurrence in response to a 10-year rainstorm for the 2013 Springs fire in Ventura County, California. Overall, the models predict a relatively high probability (60-80 percent) of debris flow for 9 of the 99 drainage basins in the burn area in response to a 10-year recurrence interval design storm. Predictions of debris-flow volume suggest that debris flows may entrain a significant volume of material, with 28 of the 99 basins identified as having potential debris-flow volumes greater than 10,000 cubic meters. These results of the relative combined hazard analysis suggest there is a moderate likelihood of significant debris-flow hazard within and downstream of the burn area for nearby populations, infrastructure, wildlife, and water resources. Given these findings, we recommend that residents, emergency managers, and public works departments pay close attention to weather forecasts and National Weather Service-issued Debris Flow and Flash Flood Outlooks, Watches, and Warnings, and that residents adhere to any evacuation orders.
\end{abstract}

\section{Introduction}

The occurrence of debris flows in response to high-intensity rainfall is well documented in recently burned areas of California (for example, Eaton, 1935; Campbell, 1975; McPhee, 1989; Cannon and others, 2008; 2010; 2011; Cannon and DeGraff, 2009; Kean and others, 2011; Staley and others, 2013a). Two recent examples highlight the destructive nature of post-fire debris flows. On December 25, 2003, a high-intensity rainstorm initiated debris flows within the Grand Prix and Old burn areas and killed 16 people near San Bernardino, California (Calif.). On February 6, 2010, debris flows produced in the Station fire burn area overtopped sediment-retention basins and damaged or destroyed 46 homes in La Crescenta, Calif. These events provide sobering examples of the threat that post-fire debris flows pose to populations, properties, infrastructure, and important natural resources within and downstream of recently burned steeplands. Although these storms produced high rainfall intensities, they were of a relative high probability with recurrence intervals under 5 years (yr) (Bonnin and others, 2006).

Wildfire causes numerous changes to the vegetative characteristics and to physical and chemical properties of the soil within a burn area. Reduction in vegetation cover on hillslopes increases soil exposure to rainfall; this can increase erosion caused by rainfall and runoff. Wildfire has also been demonstrated to increase the rate of runoff production by enhancing hydrophobicity in soils through chemical changes and by introducing ash into the soil column (Shakesby and Doerr, 2006; Gabet and Sternberg, 2008; Larsen and others, 2009). These changes ultimately contribute to increases in the rate of runoff and erosion during rainfall (Martin and Moody, 2001; Moody and Martin, 2001). The 
enhanced runoff response permits the initiation of floods and debris flows even during relatively minor rainstorms (Shakesby and Doerr, 2006; Cannon and others, 2008). Post-fire debris-flow hazards further increase in likelihood when the physical and chemical changes introduced in soil during wildfire are combined with steep slopes and an abundant supply of sediment. Given the relatively steep terrain, severity of the wildfire, and proximity of local population and infrastructure, there is an elevated risk of post-fire debris-flow hazards within and downstream of the Springs fire burn area. The purpose of this report is to provide a preliminary assessment of the likelihood and potential magnitude of post-fire debris flows in the area burned by the 2013 Springs fire in Ventura County, Calif. Published empirical methods for the intermountain western United States (Cannon and others, 2010) and modified for application in this region of southern California (Staley and others, 2013b) were used to estimate (1) the probability of debris-flow occurrence in response to a storm with a 10-yr recurrence interval, (2) the predicted volume of material transported and deposited by debris flows in response to a storm with a 10-yr recurrence interval, and (3) a combined relative-hazard ranking that incorporates the results of the probability and volume models. The model predictions were calculated at specific basin outlets and along the drainage network within and immediately downstream of the burn area.

\section{Physical Setting of the Springs Fire Burn Area}

The Springs fire burned 98 square kilometers $\left(\mathrm{km}^{2}\right)(24,250$ acres) of mountainous terrain in Ventura County, Calif. (CalFire, 2013). The Springs fire began on May 2, 2013, and was fully contained on May 11, 2013 (fig. 1). The Springs fire damaged or destroyed 22 structures and cost an estimated $\$ 10$ million to contain. In addition to the direct effects on nearby communities, several important cultural, water, and wildlife resources within and downstream of the burn area were also affected. These include the Boney Mountain State Wilderness Area, Santa Monica Mountains National Recreation Area, Point Mugu State Park, and the Satwiwa Native American Indian Natural Area. 


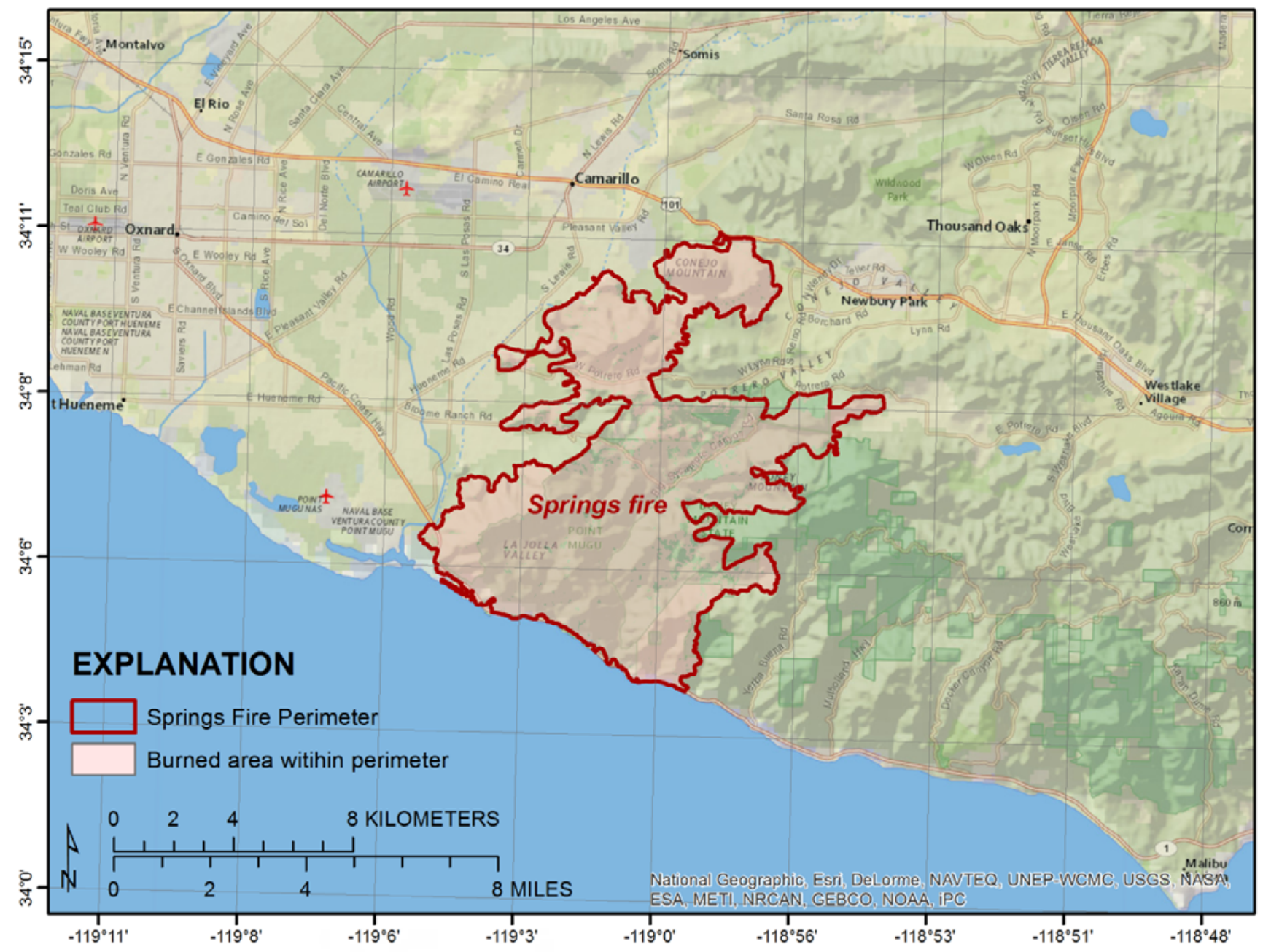

Figure 1. Overview map of the Springs fire burn area.

The area burned by the Springs fire is located in mountainous terrain with elevations ranging from sea level to 264 meters (m) with an average slope of 42 percent. A majority of the area consumed during the fire was burned at low severity ( 80 percent). Moderately burned areas composed 18 percent of the burn area, and 2 percent of the area burned by the Springs fire was identified as having a high burn severity (fig. 2) (Carl Albury, U.S. Forest Service, written commun., June 12, 2013). Areas of moderate and high burn severities fall primarily in the central and eastern portions of the burn area, where the slopes are steeper and vegetation more dense than other locations within the burn area. 


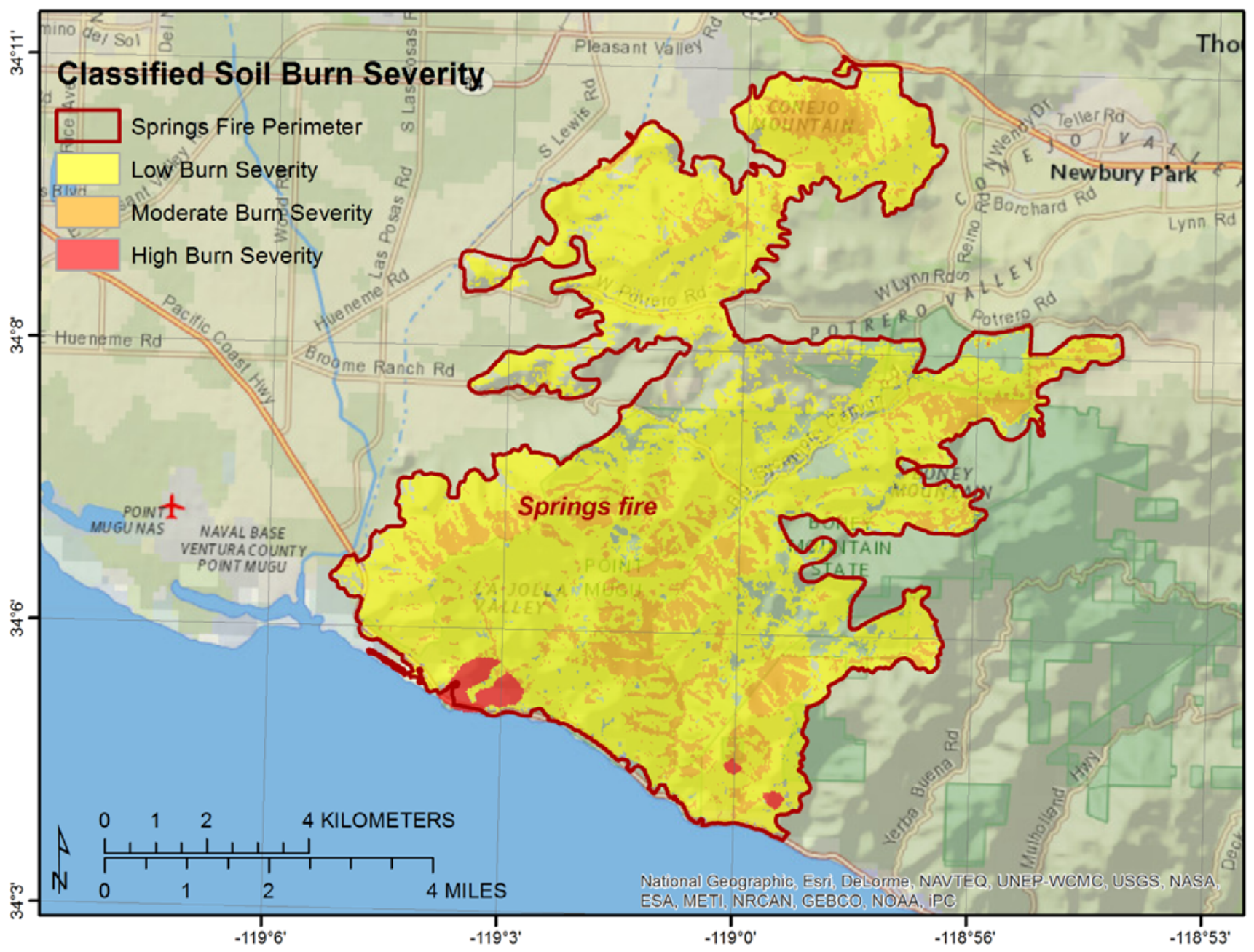

Figure 2. Burn-severity map of the Springs fire burn area.

Precipitation-frequency estimates for the burn area indicate that there is 10 -percent likelihood in any given year (that is, a 10-yr storm event) that 30 -minute (min) rainfall accumulations within the burn area will range between 12.3 and 21.5 millimeters $(\mathrm{mm})$ (0.5 and 0.85 inches) (Bonnin and others, 2006). These estimates suggest that a $10-y r$ recurrence interval is likely to produce rainfall rates that exceed rainfall intensity-duration thresholds at which post-fire debris flows are known to occur in recently burned areas of southern California and the intermountain western United States (Cannon and others, 2008; Staley and others, 2013a). We selected this storm frequency and magnitude as it represents a relatively large magnitude (in terms of total accumulation and peak storm intensities), but is still a somewhat common rainstorm.

\section{Methods Used to Estimate Debris-Flow Hazards}

The preliminary hazard assessment relies upon two empirical models to estimate the probability, volume, and combined relative hazard ranking of debris flows for selected drainage basins within the Springs fire. In this case, we use a rainstorm with a 10-yr recurrence interval for the design storm. The empirical models are based upon historical debris-flow occurrence data, rainfall storm conditions, terrain and soils information, and burn-severity data from recently burned areas in southern California. 
The probability database consists of 1,748 records from 20 burn areas from the years $2003-10$, and the volume database consists of 76 records from 13 burn areas from the years 1965-2010 (Gartner, J.E., 2013, U.S. Geological Survey, unpublished data).

In this study, we estimated the post-fire debris-flow probability, volume, and combined hazards both at the drainage-basin scale and in a spatially distributed manner along the drainage network within each basin. Basin outlets were identified for 99 drainage basins, and the characteristics of their upslope areas were calculated using a geographic information system (GIS). Debris-flow probability and volume were estimated for each basin outlet as well as along the upstream drainage networks (pixels where the contributing area is greater than or equal to $0.02 \mathrm{~km}^{2}$ ) using a method that has been applied in recently burned areas (for example, Gartner and others, 2011; Tillery and others, 2012; Verdin and others, 2012; Staley and others, 2013b; Tillery and Matherne, 2013). Estimates of debris-flow probability and volume were obtained for every 10-m pixel along the drainage network (plates 1 and 2) and were calculated using the values of independent variables upstream from each pixel. The technique used here allows for a view of how probability and volume estimates are spatially distributed within the drainage basin.

Probability estimates are based upon a logistic regression model derived from a southernCalifornia-specific database (Rupert and others, 2008), updated in 2011 to include basin-response information from the fires of 2007-10 (Cannon, S.H., 2011, U.S. Geological Survey, unpublished data). This model is designed to predict the probability of debris-flow occurrence at a point along the drainage network in response to a given storm by combining the following two equations:

$$
P=e^{x} /\left(1+e^{x}\right) \text {, }
$$

where

$$
\begin{aligned}
P & \text { is the probability of debris-flow occurrence in fractional form, and } \\
e^{x} & \text { is the exponential function where } e \text { represents the mathematical constant } 2.718 .
\end{aligned}
$$

Equation 2 is used to calculate $x$ :

$$
\begin{gathered}
x=-5.22+(0.003 \times \text { ElevRange })+\left(0.008 \times H M 50_{p c t}\right)+\left(0.024 \times b s l p_{p c t}\right)+ \\
\left(-0.007 \times C C_{p c t}\right)+(0.105 \times i 30)
\end{gathered}
$$

where

ElevRange is the range (maximum elevation-minimum elevation) of elevation values upstream of the point (in meters),

$H M 50_{p c t} \quad$ is the percentage of the upstream watershed that was burned at high or moderate severity and has slope values in excess of 50 percent (in percent), $b s l p_{p c t} \quad$ is the average gradient of the burned pixels upslope of the point (in percent), $C C_{p c t} \quad$ is the average clay content of the soils in the basin (in percent) (Schwartz and Alexander, 1995), and is the spatially averaged upslope 30 -min rainfall intensity for the design storm (in millimeters per hour $[\mathrm{mm} / \mathrm{h}])$.

In this case, we use the 30-min rainfall intensity for a 10 -yr recurrence interval storm. Probabilities predicted by the equation potentially range from 0 (least likely) to 100 percent (most likely). The predicted probabilities are assigned to 1 of 5 equal ( 20 percent) interval classes for cartographic display. 
Debris-flow volumes both at the basin outlet and along the drainage network are predicted using a multiple linear regression model (Gartner and others, 2008), which was applied in nearby southern California burn areas between 2007 and 2009 (for example, Cannon and others, 2007; Cannon and DeGraff, 2009; Staley and others, 2013b). This multiple linear regression model is used to estimate the volume $\left(V\right.$, in $\left.\mathrm{m}^{3}\right)$ of material that could issue from a point along the drainage network in response to a storm of a given rainfall intensity. This model was based upon volume estimates from 53 debris-flowproducing drainage basins in 7 burn areas in southern California and is calculated with equation 3 :

$$
\ln V=3.10+(0.17 \times \sqrt{\text { ElevRange }})+\left(0.30 \times \ln \left(H M_{k m}\right)+(0.49 \times \sqrt{i 15})\right.
$$

where

ElevRange is the range (maximum elevation-minimum elevation) of elevation values within the upstream watershed (in meters),

$H M_{k m} \quad$ is the area upstream of the calculation point that was burned at high or moderate severity (in $\mathrm{km}^{2}$ ), and

$i 15$ is the spatially-average peak 15 -min rainfall intensity for the design storm in the upstream watershed (in $\mathrm{mm} / \mathrm{h}$ ).

In this case, we use the 15-min rainfall intensity for a 10 -yr recurrence interval storm. Volume estimates were classified in order of magnitude scale ranges $0-1,000 \mathrm{~m}^{3} ; 1,000-10,000 \mathrm{~m}^{3} ; 10,000-$ $100,000 \mathrm{~m}^{3}$; and greater than $100,000 \mathrm{~m}^{3}$ for cartographic display.

\section{Debris-Flow Hazard Assessment Results}

Debris-flow probability, predicted volume, and combined relative hazard were calculated at the outlet of 99 drainage basins and along their drainage networks located within the Springs burn area. Drainage basin areas range from $0.2-5.3 \mathrm{~km}^{2}$. Debris-flow probability, volume, and combined relative hazard values represent the estimates at the outlet of each drainage basin and for each pixel along the drainage network.

\section{Debris-Flow Probability Estimates}

Overall, the basin-scale model predicts relatively low probabilities (0-20 percent) of debris flow throughout most of the burn area in response to a 10-yr, 30-min rainstorm (plate 1). Low probability values result from the high proportion of slopes that are less steeply inclined than 50 percent and relatively low burn severity throughout the burn area. Higher probability values (60-80 percent) occur within steeper, more severely burned drainages, mostly along the eastern edge of the burn area.

Of the analyzed basins, 68 out of 99 were identified as having a 0-20 percent likelihood of debris flow during the design storm. These basins occupy the central and western portion of the burn area. Slightly higher probabilities were calculated for 22 basins, which were determined to have a $20-40$ percent probability of debris-flow occurrence. Probabilities of 40-60 percent were calculated for 7 of the basins, and 2 basins were determined to have a $60-80$ percent debris flow probability. No basins were found to be within the $80-100$ percent probability classification.

The spatially distributed application of the probability model may be used to identify probability of debris-flow occurrence for specific stream reaches (plate 1). Higher probabilities were found along higher order reaches in the eastern portion of the burn area. Table 1 summarizes the total length of stream channel within each probability class. 
Table 1. Summary of the total percentage of stream length within each probability, volume, and combined hazard ranking for the Springs fire burn area. (km, kilometers; \%, percent; $\mathrm{m}^{3}$, cubic meter; <, less than; >, greater than)

\begin{tabular}{lccc}
\hline \multicolumn{1}{c}{ Model Class } & Class & Stream Length $(\mathbf{k m})$ & Stream Length $(\%)$ \\
\hline Probability & $0-20 \%$ & 457.2 & $83.2 \%$ \\
& $20-40 \%$ & 51.8 & $9.4 \%$ \\
& $40-60 \%$ & 26.8 & $4.9 \%$ \\
& $60-80 \%$ & 13.8 & $2.5 \%$ \\
& $80-100 \%$ & 0.0 & $0.0 \%$ \\
Volume & & \\
& $<1,000 \mathrm{~m}^{3}$ & 170.8 & $55.0 \%$ \\
& $1,000-10,000 \mathrm{~m}^{3}$ & 128.7 & $41.4 \%$ \\
& $10,000-100,000 \mathrm{~m}^{3}$ & 11.2 & $3.6 \%$ \\
& $>100,000 \mathrm{~m}^{3}$ & 0.0 & $0.0 \%$ \\
Combined Hazard Rank & & \\
& Low & 264.1 & $85.8 \%$ \\
& Moderate & 41.5 & $13.5 \%$ \\
& High & 2.2 & $0.7 \%$ \\
\hline
\end{tabular}

\section{Debris-Flow Volume Estimates}

Although debris-flow probabilities are relatively low for the area burned by the Springs fire, the volume model revealed that the consequence of debris flows, should they occur, are high in many locations, since estimated debris-flow volumes are relatively large throughout the burn area (plate 2). We estimated that 19 of the 99 basins could produce debris flows with volumes in excess of $10,000 \mathrm{~m}^{3}$. No basins were estimated as capable of producing debris flows with volumes greater than $100,000 \mathrm{~m}^{3}$.

The spatially distributed volume model identified that large (greater than $10,000 \mathrm{~m}^{3}$ ) debris flows were possible in many stream reaches feeding directly into the higher order stream, such as Big Sycamore Canyon and several drainages with outlets onto the Pacific Coast Highway (U.S. Highway 1). Residents and motorists should be wary of large amounts of sediment being transported by floods and debris flows in the event that debris flows are initiated during high-intensity rainfall. A summary of the total length of channel within each volume class may be found in table 1 .

\section{Combined Relative Debris-Flow Hazard Rankings}

We combined the results of the probability and the volume maps following the methods of Cannon and others (2010) to obtain an estimate of the combined relative hazard of the drainage basins defined for the Springs fire (plate 3). Most of the analyzed basins were within the low relative hazard class; 65 of the 99 basins were calculated to have a cumulative score of less than 4 out of a possible 9 . These low values reflect the relatively gentle gradients and lower burn severity within these watersheds. Moderate hazards (cumulative scores between 4 and 6 out of a possible 9) were calculated for 32 of the 99 basins. Moderate hazards were assigned to basins that had a low or moderate likelihood of producing moderate-sized (1,000-10,000 $\mathrm{m}^{3}$ ) debris flows. The remaining 2 basins (Basins 39 and 40 in plate 3) were calculated as having a high hazard ranking, with cumulative scores of 7 or greater out of a possible 9. These basins are typically larger and slightly steeper than those in the low hazard class, and are found in the eastern portion of the burn area. Areas within and below these watersheds are of particular 
concern, and include areas within Point Mugu State Park and along Big Sycamore Canyon Road. A summary of the total length of stream channel within each hazard class may be found in table 1 .

\section{Limitations of Hazard Assessments}

This hazard assessment used a 10-yr recurrence interval storm to predict the probability, volume, and combined relative hazard of debris flows in basins burned by the 2013 Springs fire in California. Differences in model predictions and actual debris-flow occurrence will arise with differences in actual storm duration and intensity. The occurrence of higher rainfall intensities or longer storm durations may increase the probability or volume of potential debris flows.

In addition, this study relies upon readily available geospatial data, the accuracy and precision of which may influence the estimated likelihood and magnitude of post-fire debris flows. However, local conditions (such as debris supply) certainly influence both the probability and volume of debris flows. Unfortunately, locally specific data are not presently available at the spatial scale of the post-fire debrisflow hazard assessment. As such, local conditions that are not constrained by the model may serve to dramatically increase or decrease the probability and(or) volume of a debris flow at a basin outlet. The input geospatial data are also subject to error based upon mapping resolution, elevation interpolation techniques, and mapping and(or) classification methods. Finally, this assessment is specific to debrisflow hazards; hazards from flash-flooding are not described in this study and may be significant.

This assessment also characterizes potential debris-flow hazards at a static point in time immediately following wildfire. Studies of post-fire debris flows in southern California and the intermountain western United States have indicated that debris-flow activity in recently burned areas typically occurs within $2 \mathrm{yr}$ of wildfire (Cannon and Gartner, 2005; Cannon and others, 2008; Gartner and others, 2008). As vegetation cover and soil properties return to pre-fire conditions, the threat of debris-flow activity decreases with time elapsed since wildfire. Conversely, the hazards from flashflooding may persist for several years after wildfire.

Finally, this work is preliminary and is subject to revision. It is being provided due to the need for timely "best science" information. The assessment is provided on the condition that neither the U.S. Geological Survey nor the Unites States Government may be held liable for any damages resulting from the authorized or unauthorized use of the assessment.

\section{Summary and Conclusions}

This hazard assessment characterizes the post-fire debris-flow hazards that may exist within and below the 2013 Springs fire, Ventura County, Calif. We use geospatial data related to basin morphometry, burn severity, soil properties, and rainfall characteristics to estimate the probability and volume of debris flows that may occur in response to a 10 -yr recurrence interval rainstorm. We have identified that probabilities of debris-flow occurrence in response to the design rainstorm are relatively low throughout the burn area, with only 9 of the 99 defined basins having a probability of debris-flow greater than 40 percent. However, the volume model predicts that if debris flows are initiated, the consequences could be significant in certain areas, as potential debris flows may be large. Debris-flow modeling predicts that 19 of the 99 basins are capable of producing debris flows with volumes greater than $10,000 \mathrm{~m}^{3}$. Combining the probability and volume models into a combined hazard ranking indicates that 34 basins were of moderate or high threat of post-fire debris-flow activity; these basins obtained a score greater than 3 (of a possible 9).

Large predicted volumes (greater than $10,000 \mathrm{~m}^{3}$ ) and moderate relative hazard rankings (cumulative scores between 4 and 6 out of a possible 9) identified by the spatially distributed models 
indicate a relatively high likelihood (greater than 40 percent) of debris-flow effect to infrastructure, including road, trails, and other important natural and cultural resources located both within and downstream of the burn area. We recommend that residents and visitors remain vigilant and take responsible actions to prevent injury or loss of life from post-fire debris flows and flash floods that may occur in response to high-intensity rainfall during short-lived summer convective thunderstorms and longer-duration winter storms. Specifically, residents, tourists, and motorists should adhere to evacuation guidelines and closures of roads, trails, and open space.

\section{References Cited}

Bonnin, G.M., Martin, D., Lin, B., Parzybok, T., Yekta, M., and Riley, D., 2006, Precipitation frequency atlas of the United States: Silver Spring, Md., National Weather Service, National Oceanic and Atmospheric Administration (NOAA) atlas 14, v. 1, version 5, accessed July 30, 2013, at http://hdsc.nws.noaa.gov/hdsc/pfds/.

CalFire, 2013, Springs fire incident information: CalFire, accessed November, 2013, at http://cdfdata.fire.ca.gov/incidents/incidents_details_info?incident_id $=780$.

Campbell, R.H, 1975, Soil slips, debris flows, and rainstorms in the Santa Monica mountains and vicinity, southern California: U.S. Geological Survey Professional Paper 851, 55 p.

Cannon, S.H., Boldt, E.M., Laber, J.L., Kean, J.W., and Staley, D.M., 2011, Rainfall intensityDuration thresholds for postfire debris-flow emergency-response planning: Natural Hazards, v. 59, no. 1, p. 209-236.

Cannon, S.H., and DeGraff, J., 2009, The increasing wildfire and post-fire debris-flow threat in western USA, and implications for consequences of climate change, chap. 9 of Sassa, K., and Canuti, P., eds., Landslides-Disaster risk reduction: Springer, Berlin, p. 177-190.

Cannon, S.H., and Gartner, J.E., 2005, Wildfire-related debris flow from a hazards perspective, chap. 15 of Jakob, M., and Hungr, O., eds., Debris-flow hazards and related phenomena: Chichester, U.K., Springer-Praxis Books in Geophysical Sciences, p. 321-344.

Cannon, S.H., Gartner, J.E., Michael, J.A., Bauer, M.A., Stitt, S.C., Knifong, D.L., McNamara, B.J., and Roque, Y.M., 2007, Emergency assessment of debris-flow hazards from basins burned by the 2007 Canyon fire, Los Angeles County, southern California: U.S. Geological Survey Open-File Report 2007-1415, 1 sheet, at http://pubs.usgs.gov/of/2007/1415/.

Cannon, S.H., Gartner, J.E., Rupert, M.G., Michael, J.A., Rea, A.H., and Parrett, Charles, 2010, Predicting the probability and volume of postwildfire debris flows in the intermountain western United States: Geological Society of America Bulletin, v. 122, p. 127-144.

Cannon, S.H., Gartner, J.E., Wilson, R., Bowers, J., and Laber, J., 2008, Storm rainfall conditions for floods and debris flows from recently burned areas in southwestern Colorado and southern California: Geomorphology, v. 96, no. 3-4, p. 250-269.

Eaton, E.C., 1935, Flood and erosion control problems and their solution: Proceedings of the American Society of Civil Engineers, v. 62, no. 8, p. 1,302-1,362.

Gabet, E., and Sternberg, P., 2008, The effects of vegetative ash on infiltration capacity, sediment transport, and the generation of progressively bulked debris flows: Geomorphology, v. 10, no. 4, p. 666-673.

Gartner, J.E., Cannon, S.H., and Santi, P.M, 2011, Implementation of post-fire debris-flow hazard assessments along drainage networks, southern California, U.S.A., in Genevois, R., Hamilton, D.L., and Prestininzi, A., eds., International Conference on Debris Flow Hazards Mitigation/Mechanics, Prediction, and Assessment, 5th, Padua, Italy, June 7-11, 2011, Casa Editrice Universita La Sapienza, Rome, p. 855-863. 
Gartner, J.E., Cannon, S.H., Santi, P., and Dewolfe, V., 2008, Empirical models to predict the volumes of debris flows generated by recently burned basins in the western U.S.: Geomorphology, v. 96, no. 3-4, p. 339-354.

Kean, J.W., Staley, D.M., and Cannon, S.H., 2011, In situ measurements of post-fire debris flows in southern California - Comparisons of the timing and magnitude of 24 debris-flow events with rainfall and soil moisture conditions: Journal of Geophysical Research, v. 116, F4:F04019.

Larsen, I.J., MacDonald, L.H., Brown, E., Rough, D., Welsh, M.J., Pietraszek, J.H., Libohova, Z., de Dios Benavides-Solorio, J., and Schaffrath, K., 2009, Causes of post-fire runoff and erosion-Water repellency, cover, or soil sealing?: Soil Science Society of America Journal, v. 73, no. 4, p. 1,393-1,407.

Martin, D.A., and Moody, J.A., 2001, Comparison of soil infiltration rates in burned and unburned mountainous watersheds: Hydrological Processes, v. 15, p. 2,893-2,903.

McPhee, J.A., 1989, The control of nature: New York, Farrar, Straus and Giroux, 272 p.

Moody, J.A., and Martin, D.A., 2001, Initial hydrologic and geomorphic response following a wildfire in the Colorado Front Range: Earth Surface Processes and Landforms, v. 26, no. 10, p. 1,049-1,070.

Rupert, M.G., Cannon, S.H., Gartner, J.E., Michael, J.A., and Helsel, D.R., 2008, Using logistic regression to predict the probability of debris flows in areas burned by wildfires, southern California, 2003-2006: U.S. Geological Survey Open-File Report 2008-1370, 20 p., http://pubs.usgs.gov/of/2008/1370/.

Schwartz, G.E., and Alexander, R.B., 1995, Soils data for the conterminous United States derived from the NRCS State Soil Geographic (STATSGO) Database: U.S. Geological Survey Open-File Report 95-449, accessed July 2013, at http://water.usgs.gov/GIS/metadata/usgswrd/XML/ussoils.xml.

Shakesby, R.A., and Doerr, S.H., 2006, Wildfire as a hydrological and geomorphological agent: EarthScience Reviews, v. 74, no. 3-4, p. 269-307.

Staley, D.M., Gartner, J.E., Smoczyk, G.M., Reeves, R.R., 2013a, Emergency assessment of post-fire debris-flow hazards for the 2013 Mountain fire, southern California. U.S. Geological Survey Open File Report 2013-1249, 13 p., 3 plates, at http://pubs.usgs.gov/of/2013/1249/.

Staley, D.M., Kean, J.W., Cannon, S.H., Schmidt, K.M., and Laber, J.L., 2013b, Objective definition of rainfall intensity - Duration thresholds for the initiation of post-fire debris flows in southern California: Landslides, v. 10, no. 5, p. 547-562.

Tillery, A.C., and Matherne, A.M., 2013, Postwildfire debris-flow hazard assessment of the area burned by the 2012 Little Bear fire, south-central New Mexico: U.S. Geological Survey Open-File Report 2013-1108, 15 p., 3 plates, at http://pubs.usgs.gov/of/2013/1108/.

Tillery, A.C., Matherne, A.M., and Verdin K.L., 2012, Estimated probability of postwildfire debris flows in the 2012 Whitewater-Baldy Fire burn area, southwestern New Mexico: U.S. Geological Survey Open-File Report 2012-1188, 11 p., 3 plates, at http://pubs.usgs.gov/of/2012/1188/.

Verdin, K.L., Dupree, J.A., and Elliot, J.G., 2012, Probability and volume of potential postwildfire debris flows in the 2012 Waldo Canyon Burn Area near Colorado Springs, Colorado: U.S. Geological Survey Open-File Report 2012-1158, 8 p., at http://pubs.usgs.gov/of/2012/1158/. 